\title{
EARLY DEVELOPMENT OF INOCYBE
}

\author{
GERTRUDE E. DOUGLAS \\ (WITH PLATES XVIII-XXII)
}

During a collecting trip with Professor Atkinson at Coy Glen, near Ithaca, New York, on August 25, I9I4, we came upon a large quantity of Inocybe infelix in all stages of development. At that time Professor AtKinson was particularly interested in obtaining Inocybe material, as he had in mind the publication of a monograph of the genus. He felt that, before the systematic relationship could be determined with absolute certainty, there was need for more morphological work on the developmental stages of these plants. Accordingly he turned over this material to me as a nucleus of a paper on the development of Inocybe. Two years later, in July, while collecting fungi in the Adirondacks near Seventh Lake, material of $I$. eutheloides and $I$. geophylla was added, the latter collected by Miss Lena B. WALker. In the following summer the same locality furnished $I$. hystrix, collected by Professor Atkinson. The $I$. obscura material came from a hard gravelly path in Coy Glen on September 24, I9r6.

All the Inocybe forms studied here are ground-inhabiting, and were collected from places where the soil was compact and comparatively poor in humus. The determinations were made by Professor Atkinson from mature plants springing up from the same mycelium as the young buttons taken for study. ${ }^{\mathrm{I}}$ It is certainly to be regretted that this paper was not put forward at that time, before the untimely death of Professor Atkinson, who felt so keenly the need of a closer cooperation of the systematist with the morphologist in working out plant relationships. The

${ }^{x}$ Plants were fixed in the field in medium chromo-acetic acid, care being taken to remove as much of the soil as possible before dropping them into the fluid. The washing afterward removed most of the gritty particles. After dehydration they were cleared in cedar oil and imbedded in $5^{\circ}$ paraffine. Sections were cut $5^{-7} \mu$ in thickness and stained with fuchsin, after having been previously treated with tannic acid. This method had been found to be most satisfactory for photographing other forms of agarics (9), and proved equally efficient in this case. 
development proved to be so similar in all the forms studied that it will be unnecessary to describe it separately for each one. Accordingly, a general account of the method of growth will be given and any minor specific variations noted from time to time.

PRIMORDIUM OF BASIDIOCARP.-Very young stages in the development of the fruit body were found in only two of the five species, in $I$. hystrix (fig. 53) and $I$. geophylla (fig. 70). The button of $I$. hystrix measures $0.6 \times 0.35 \mathrm{~mm}$., and is composed of loosely interwoven hyphae ranging from 2 to $3 \mu$ in diameter. In the basal end there is a more deeply staining region, conical in shape, where the elements are considerably thicker. This represents the primordium of the stem whose hyphae, multiplying very rapidly, are advancing into the fundamental tissue above. The young button at the right in fig. 70 of $I$. geophylla is composed of interlaced fibers $\mathrm{I}-2 \mu$ thick in the denser stem primordial region inside and $2-4 \mu$ on the outside, where apparently they are disintegrating and wearing off through the contact with the soil.

DIFFERENTIATION OF PILEUS AND STEM PRIMORDIA.--The domeshaped stem primordium at the base of the fruit body continues to advance upward within the fundamental tissue. After a time the hyphae in the apical region, which have been branching profusely and twining in and out through the interstices of the young button, change their general upward direction and radiate outward on all sides (fig. 55). Thus the pileus fundament appears in the form of a more or less globular cap, separated by an annular furrow from the primordium of the stem below (figs. I, 2, 2 I, 39, 54, 55, $7 \mathrm{I})$. This method of progressive differentiation of first the stem and then the pileus from the apex of the former has previously been described by MöLler (Io) for Rozites gongylophara, by Atkinson (8) for Lepiota cristata and L. seminuda, by Douglas (9) and SAwyer (I2) for species of Cortinarius, by SAWyer (I I) for Pholiota squarrosa, P. flammans, and P. adiposa, and by WALker (13) for Tubaria furfuracea among the endogenous forms.

Blematogen.--The remnant of the original fundamental tissue, still enveloping the fundaments of pileus and stem, becomes the true "universal veil," or, as we shall call it, the blematogen. This name was proposed by Atkinson $(\mathbf{2}, \mathbf{3})$ because of the indefi- 
niteness in the application of the former term by the earlier writers. Although there are minor differences in its character and considerable variation in its final disposition, it has been found to be a homologous structure in all endogenous forms. In the Amanita type, as illustrated by Amanitopsis vaginata (4), the blematogen is separated from the pileus by a clean-cut cleavage layer and forms the volva. In all the other forms it becomes more or less "concrete" with the pileus, so that in the majority of cases it is impossible to distinguish where the pileus leaves off and the blematogen begins. In Agaricus forms (1, 2, 6) considerable blematogen enters into the formation of the cortex of the pileus. In others it becomes the cuticle (Cortinarius anfractus and $C$. armillatus, 9). Often it is shed in the form of scales (Cortinarius distans, 9) which may be mealy or powdery (Lepiota cristata, 8, Coprinus micaceus, 7). In Pholiota (II) scales are formed from the blematogen which partly gelatinize. Frequently fibrillose scales of blematogen persist in the mature plants, as in Lepiota clepeolaria (5) and Coprinus comatus (7).

In four of these species of Inocybe the blematogen is a very delicate structure, which very soon disappears from the surface of the pileus. In I. obscura (pl. XVIII), I. infelix (pl. XIX), I. entheloides (pl. XX), and I. hystrix (pl. XXI) the pileus seems to expand through the blematogen to the surface, where it gives off the characteristic silky Inocybe fibrils. There is a gradual transition in the size of the hyphae from the inner ones, about $2 \mu$ in diameter in the denser region, to the loose radiating ones on the outside which measure $4^{-6} \mu$ in thickness. These on the outside take the stain more deeply than those within, and behave generally as disintegrating hyphae.

The condition is slightly different in $I$. geophylla, which belongs to a section of the genus characterized by a pileus which does not crack and which is covered with interwoven fibrils. That these interwoven fibrils are of blematogenous origin seems clear from the fact that they appear in the early stages before the pileus primordium has advanced to the surface of the fruit body (fig. $7 \mathrm{I}$ ). They form a deeply staining thin envelope over the whole of the developing basidiocarp. This envelope might possibly be 
considered as a "primary universal veil" or protoblem, ${ }^{2}$ such as occurs in addition to the blematogen over the surface of young buttons of Agaricus campestris. It does not, however, show as a definite layer in buttons younger than the one shown in fig. $7 \mathrm{I}$, although there are hyphae more deeply stained and with larger diameters at the surface in some (fig. 70). The irregularity of the latter wc 'd seem to indicate that they are the ends of hyphae undergoing disintegration on account of their contact with the soil. No trace of a protoblem was found in the four other species. This of course may be due to the fact that it was washed off during the rather vigorous treatment necessary to remove the grit particles, but it hardly seems possible that no trace would be left had it existed. The envelope of interwoven fibrils persists in I. geophylla (pl. XXII) in the oldest stages collected, and forms here the outer portion of a duplex universal veil such as was described in Cortinarius anfractus and C. armillatus (9). From this loose fibrils arise (fig. 79). Within is a looser, much more delicate tissue with large air spaces. The latter becomes more or less concrete with the pireus at the apex of the fruit body, and shows most clearly between the pileus margin and the stem below the gill cavity.

PRIMORDIUM OF HYMENOPHORE.-Following the differentiation of the stem and pileus primordia, or possibly proceeding at the same time in I. infelix (fig. 2I), the fundament of the hymenophore makes its appearance (figs. 3, 4, I6, I9, 22, 23, 35, 36, 40, 4I, 47, $48,72,73)$. The hyphae in the annular furrow left between the pileus and stem multiply very profusely and turn perpendicularly downward from the more laterally directed fibers of the pileus trama. They beconie very rich in protoplasm, as shown by their propensity for stain. They are very slender, with more or less pointed ends, so that they are able to push their way easily through the ground tissue. Such a rapid increase in growth here, while practically none is taking place in the blematogen, brings about a stretching and finally a rupturing of the latter tissue, bringing about the formation of the annular cavity (figs. 3, 4). Usually a well defined annular cavity does not make its appearance until the fruit body is slightly older and the palisade layer is organized

${ }^{2}$ See Atrinson $(2, \mathbf{3})$ for a definition of this term. 
(figs. 24, 25, 37, 42, 56, 74). At first the extent of growth of these fibers is very unequal, and in consequence the primordial surface is very uneven. Gradually, however, the ends of the hyphae become more blunt and even, and beginning at the stem a palisade layer commences to extend outward toward the margin of the pileus. The newest elements are always the smallest. These occur nearest the stem where they are also the most crowded. As the palisade layer passes outward into the primordium the elements appear to be less crowded, more irregular, and larger in diameter. The primordium of the hymenophore gradually passes into pileus margin, where the hyphae are strongly hyponastic and grow irregularly into the blematogen over the stem (fig. 67).

Absence of marginal veil.-As the interstitial growth of the hyphae pushes the margin of the pileus outward, the gill cavity becomes larger and larger, and in consequence the blematogen, which lies between the pileus and stem, is constantly reduced. Whatever fibrils or scales are left on the margin of the pileus are remnants of this. No instance could be found which showed clearly any additional growth of fibers from the margin of the pileus or from the stem into the fundamental tissue which lies between these two regions. The pileus margin is strongly hyponastic and its hyphae, curving downward and inward, grow into the blematogen, but do not reach completely across to the stem (figs. I I, 3I, 56, 61, 67, 74, 77, 79). The delicate cobwebby fibrils, which cover the gill cavity in young buttons and usually rupture very early (fig. 65), are evidently of blematogenous origin. In the forms studied here there is no marginal veil in the sense of Atkinson, who considered it a structure at least in part "sui generis" $(2,3)$. This condition is what we should naturally expect, as one of the characteristics of the genus Inocybe in the systematic works is the absence of a marginal veil. By the time the period of vigorous lateral expansion of the pileus is reached, scarcely a trace of the blematogen remains (fig. 65).

Development of GiLls. The gills develop in exactly the same manner as has been described previously for all endogenous forms (excepting those of the Amanita type), very careful and detailed accounts of which may be found in AtKinson's later papers $(6,7$.). 
As has been shown, the pileus begins its development at the stem and gradually extends its organization into the hymenophore primordium at the margin of the pileus (fig. 67). Growth continues to be centrifugal. The gill ridges start to develop at the stem in regular spaced areas and radiate outward toward the margin. On account of the very great density of the palisade elements and the continuous addition of new fibers by branching of the palisade elements, the surface of the latter is soon thrown out into folds (figs. I8, 38, 66). Multiplication of hyphae nevertheless continues to go on, and with it certain elements in the layer subjacent now begin to elongate rapidly and to carry downward the much crowded palisade layer. Since the growth of these young salients begins at the stem, the gills elongate first in this region. Passing outward the ridges become less developed until they disappear in the even palisade surface (figs. 7-10, 26-30, $42-46,56-60,67)$. Elongation of the elements of the trama continues while the ridges are progressing outward until mature gills, extending from the stem to the pileus margin, are fully developed. As these radiating rows get farther and farther apart, secondary gills form in the same manner between them. Before the basidia mature, certain elements of the palisade layer push out very rapidly and form cystidia (figs. 49, 68, 69), the nucleus of one of which shows plainly in fig. 49. Successive stages in the development of young gill salients are shown in the high-power photographs of $I$. entheloides (figs. 50-52). Occasionally the gill cavity is strongly arched, ${ }^{3}$ and the development of the ridges appears to begin on the stem, a circumstance which brings about appearances such as are shown in figs. 43 and 44 in sections cut parallel to the medium axis. In consequence the salients here are cut nearly perpendicular to their direction of growth, and the gill cavity which extends in between them appears as a series of little pockets. A similar appearance at the margin is often caused by cutting perpendicular to the salients on the enrolled edge of the pileus (figs. I4, I 5, 34, 64). The development of these plants was not carried beyond the stages represented in figs. 49, 68, and 79, in which well developed cystidia,

3 See Atrinson $(6,7)$ for a complete explanation of these appearances. 
but as yet only primordia of basidia and paraphyses, had formed on the half mature gill salients.

\section{Summary}

I. Basidiocarps are developed from young buttons of fundamental tissue, within which is organized a growing region of very densely interwoven hyphae of small diameters. By progressive growth the stem is first formed, and later, at the stem apex, the pileus fundament, while the ground tissue on the outside becomes the blematogen or universal veil. No marginal veil is formed. The blematogen is finally completely lost or becomes concrete with the pileus.

2. The gills develop as previously described for forms of the Agaricaceae (not of the Amanita type). In the furrow between the pileus and stem fundaments a dense irregular hymenophore primordium is formed, which is soon replaced by an even palisade layer. Crowding of the elements in the palisade layer, due to excessive branching, causes the surface to be thrown outward into folds, which are then carried downward by the elongation of hyphae of the layer subjacent to them. The ridges develop from the stem centrifugally in regular radial rows. Later secondary gills form in a similar manner between them.

In conclusion I wish to express my appreciation to Professor W. W. RowleE for his kindness in allowing me the use of the photographic apparatus in the College of Arts and Sciences.

\section{N.Y. State College of Agriculture ITHACA, N.Y.}

\section{LITERATURE CITED}

I. Atkinson, Geo. F., The development of Agaricus campestris. Bot. Gaz. 42:24I-264. pls. 7-I2. I906.

2. - The development of Agaricus arvensis and A. comtulus. Amer. Jour. Bot. I:3-22. pls. I, 2. I9I4.

3. - Homology of the universal veil in Agaricus. Mycol. Centralbl. 5:13-20. pls. I-3. I9I4.

4. - - The development of Amanitopsis vaginata. Ann. Mycol. r2:369392. pls. I7-I9. I914. 
5. - - The development of Lepiota clypeolaria. Ann. Mycol. r2:346356. pls. I3-I6. I9I4.

6. - Morphology and development of Agaricus rodmani. Proc. Amer. Phil. Soc. 54:309-343. pls. 7-13. I9 5.

7. - - Origin and development of the lamellae in Coprinus. Bot. Gaz. 6r:89-г30. pls. 5-12. г9г6.

8. —— - The development of Lepiota cristata and L. seminuda. Mem. N.Y. Bot. Gard. 6:209-228. pls. 21-26. I9I6.

9. Douglas, G. E., A study of development in the genus Cortinarius. Amer. Jour. Bot. 8:319-335. pls. 8-I3. г9г6.

ı. Möller, A., Die Pilgärten einiger süd amerikanischer Ameisen. Bot. Mittheil. Tropen 6:I-I27. pls. I-7. I893.

Ir. Sawyer, W. H., The development of some species of Pholiota. Bot. GAZ. 64:206-229. pls. I6-20. I9I7.

I2. - The development of Cortinarius pholidius. Amer. Jour. Bot. 4:520-532. pls. 28, 29. I9I7.

13. Walker, L. B., Development of Pluteus admirabilis and Tubaria furfuracea. Bot. Gaz. 58: I-2I. pls. I-5. I9I9.

\section{EXPLANATION OF PLATES XVIII-XXII}

FIGS. I-I 5, 2I-34, 39-46, 53-65, 68, 70-8I were taken with a Zeiss horizontal camera and a Spencer Lens Co. I6 mm. objective; the others were photographed by means of a Bausch \& Lomb vertical camera and Zeiss lenses.

\section{PLATE XVIII}

Inocybe obscura

Figs. I, 2.-Median sections of two young fruit bodies, showing differentiation within blematogen of stipe and pileus fundaments; $\times_{34}$.

FIGS. 3, 4.-Median and tangential sections of older basidiocarp in which hymenophore primordium and gill cavity have appeared; $\times_{34}$.

FIGS. 5, 6.-Median and tangential sections of fruit body, showing palisade layer; $X_{34}$.

FIGS. 7-Io.-Series of median and tangential sections of a fruit body in which young gill salients have appeared; $\times 34$.

FIGS. I I-I 5.-Median and tangential sections of older fruit body, showing gills more strongly developed; fibrillose hyphae from pileus have replaced blematogen; $\times 34$.

FIgs. I6, I9.-Details from figs. 4 and 3 respectively, showing hymenophore primordium; XI58.

FIGs. I7, 20.-Details from figs. 6 and 5 respectively, showing crowded palisade layer previous to formation of gills; $X_{15} 8$.

FIG. I8.-Young gill salients; detail from fig. $9 ; \times{ }_{5} 8$. 


\section{PLATE XIX}

\section{Inocybe infelix}

FIG. 21.-Median section of young fruit body, showing organization of stem, pileus, and hymenophore fundaments within blematogen; $\times_{34}$.

FIGS. 22, 23.-Median and tangential sections of slightly older basidiocarp in which gill cavity has appeared; $\times 34$.

FIGS. 24, 25.-Median and tangential sections of fruit body in which palisade layer is developing; $X_{34}$.

Figs. 26-30.-Median and tangential sections of fruit body in which gills are beginning to form; $\times_{34}$.

FIGS. 3I-34.- - Series of sections from older fruit body with developing gills; $\times 34$.

Figs. 35, 36.-Details from figs. 22 and 23 respectively, showing hymenophore primordium; $\times 240$.

FIG. 37.-Detail from fig. 25 , showing palisade layer; $\times 240$.

FIG. 38. -Detail from fig. 28 , showing young gill salients; $\times 240$.

\section{PLATE $X X$}

\section{Inocybe eutheloides}

FIG. 39.- Young button in which pileus and stem primordia are outlined within loose blematogen; $\times_{34}$.

FIGS. 40, 4I.-Median and tangential sections of older fruit body, showing growth of pileus into blematogen layer and hymenophore primordium; $\times_{34}$.

FIGs. 42-46.-Median and tangential sections of fruit body in which gills are forming; $\times 34$.

FIGs. 47, 48.-Details from figs. 40 and 4 I respectively, showing hymenophore primordium; $\times_{\mathrm{I}} 58$.

FIG. 49:-Section of gills of more mature fruit body, showing developing cystidia; $\times 158$.

FIGs. 50-52.-Series of sections from fruit body of figs. $4^{2-46}$, showing successive stages in formation of gill ridges; $X_{{ }_{5} 8}$.

\section{PLATE $X X I$}

\section{Inocybe hystrix}

FIG. 53.- Young button, showing fundamental tissue into which stem primordium is advancing; $\times_{34}$.

FIGs. 54, 55.-Median sections of two fruit bodies in which pileus fundament is advancing into blematogen; $\times 34$.

FIGS. 56-60.-Series of longitudinal sections, showing development of gill salients; $\times 34$.

Figs. 6I-64. - Series of sections from slightly older fruit body; $\times_{34}$.

FIG. 65.-Median section from nearly mature fruit body in which pileus has begun to expand; $X_{34}$.

FIG. 66.-High power photograph from fruit body of figs. ${ }_{56} 60$; $\times{ }_{15} 8$. 
Fig. 67.-Detail from fig. 6r, showing progressive differentiation of hyphae from primordial hymenophore into pileus margin; $X_{15} 8$.

FIG. 68.-Tangential section of fruit body of fig. 65 , showing developing cystidia; $\times 34$.

FIG. 69.-Detail from fig. $68 ; \times 158$.

PLATE XXII

\section{Inocybe geophylla}

FIG. 70.-Longitudinal sections of young buttons; $\times_{34}$.

FIG. 7I.-Median section in which pileus and stem fundaments are outlined within a 2-layered blematogen; $\times 34$.

Figs. 72, 73.-Median and tangential sections of fruit body in which primordium of hymenophore is appearing; $\times_{34}$.

FIGs. 74-76.-Median and tangential sections of older fruit body in which palisade layer has become organized and first gill salients are appearing; $\times_{34}$.

FIGS. $77,78 .-$ Median and tangential sections of older fruit body; $\times_{34}$.

FIGs. 79-8r:-Older fruit body in which gills are nearly mature and on which cystidia have developed; duplex universal veil still present over whole fruit body; $\times 34$. 

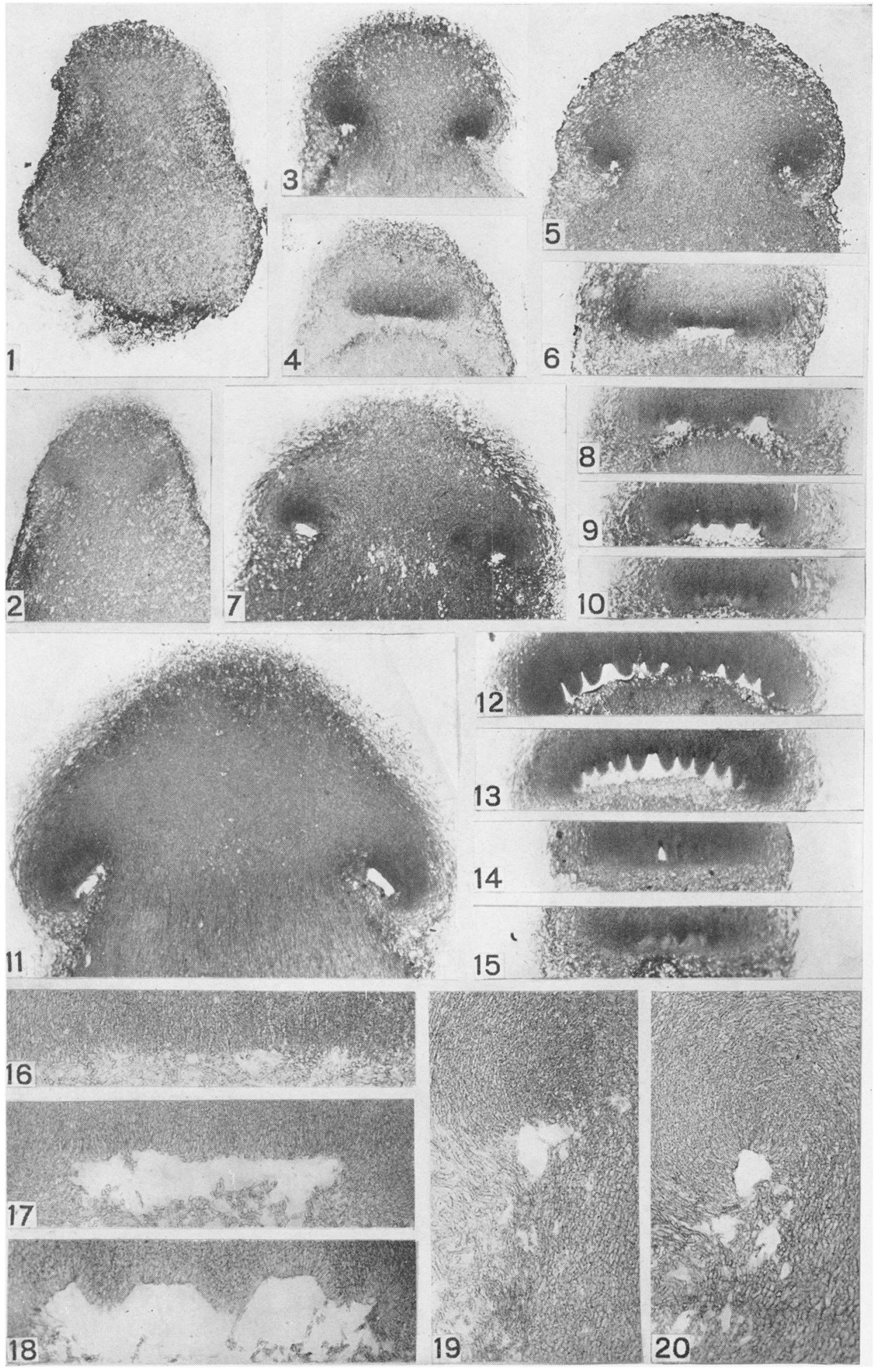

14
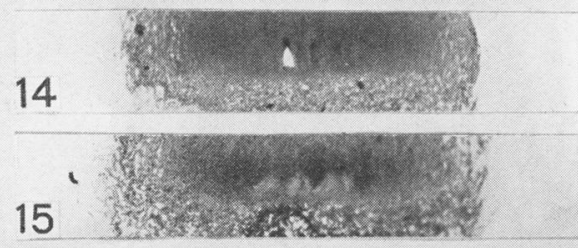

\section{DOUGLAS on INOCYBE}

This content downloaded from 080.082.077.083 on February 19, 2018 19:23:19 PM

All use subject to University of Chicago Press Terms and Conditions (http://www.journals.uchicago.edu/t-and-c). 

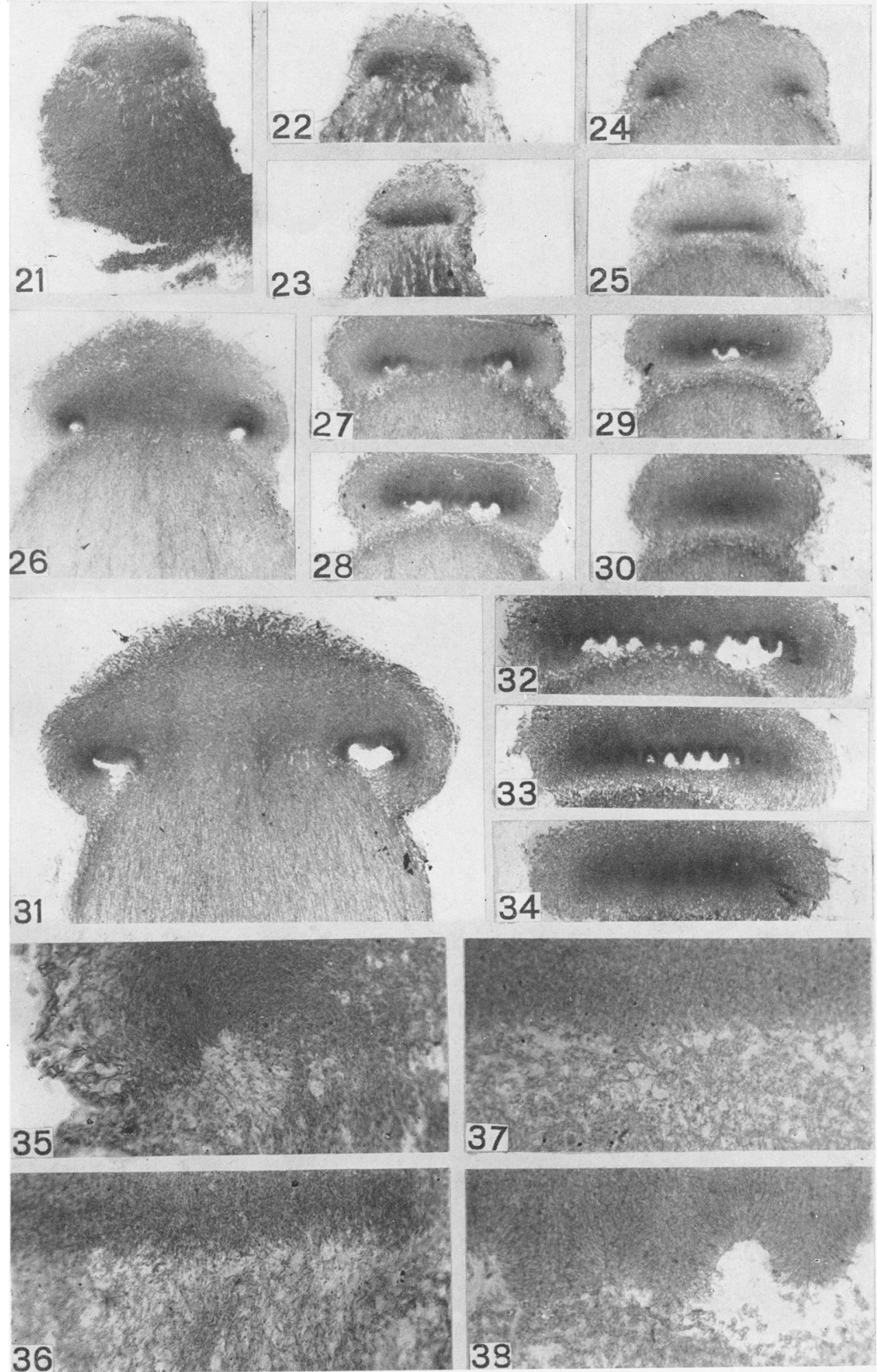

\section{DOUGLAS on INOCYBE}

This content downloaded from 080.082.077.083 on February 19, 2018 19:23:19 PM All use subject to University of Chicago Press Terms and Conditions (http://www.journals.uchicago.edu/t-and-c). 

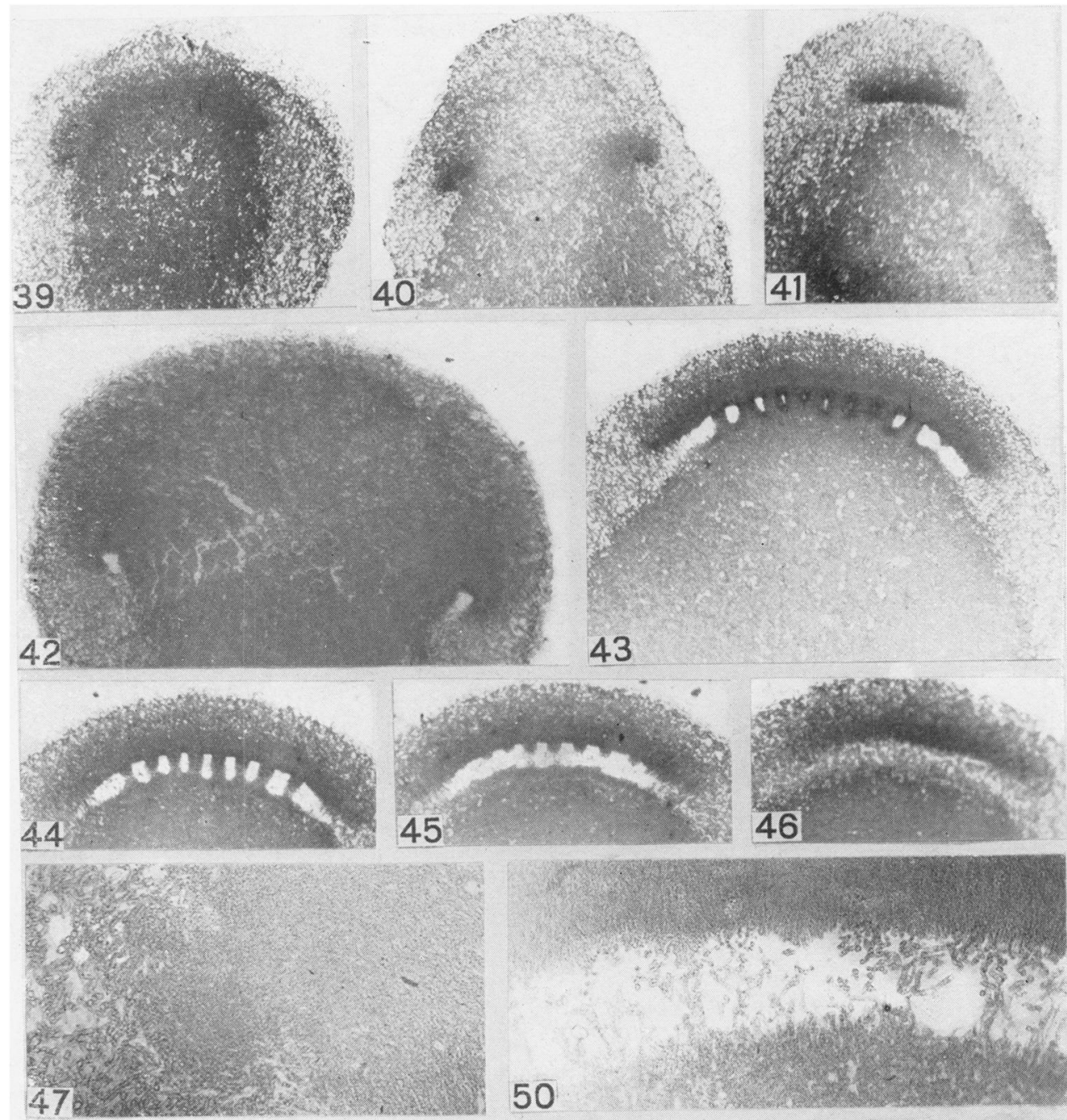

50
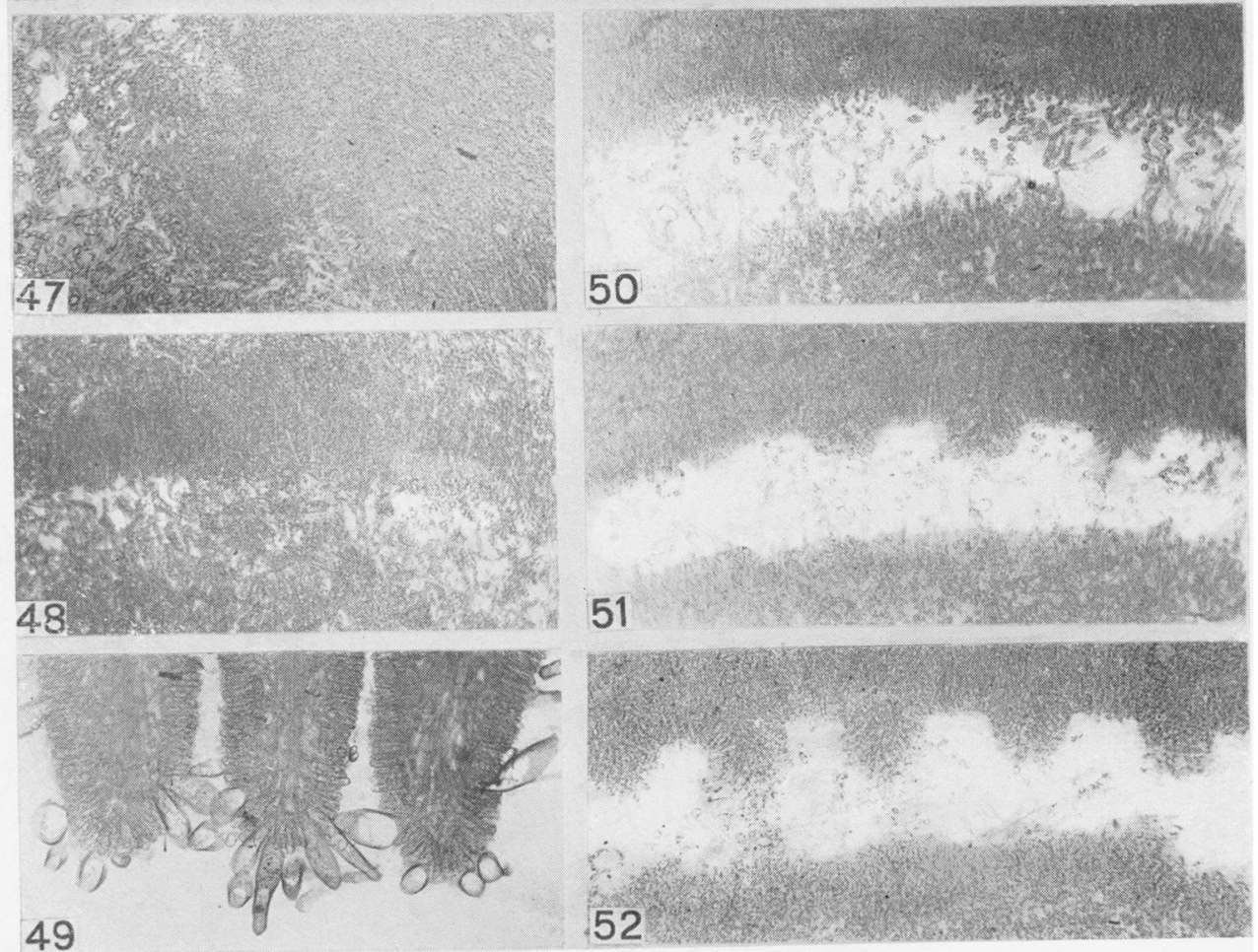

DOUGLAS on INOCYBE

This content downloaded from 080.082.077.083 on February 19, 2018 19:23:19 PM

All use subject to University of Chicago Press Terms and Conditions (http://www.journals.uchicago.edu/t-and-c). 

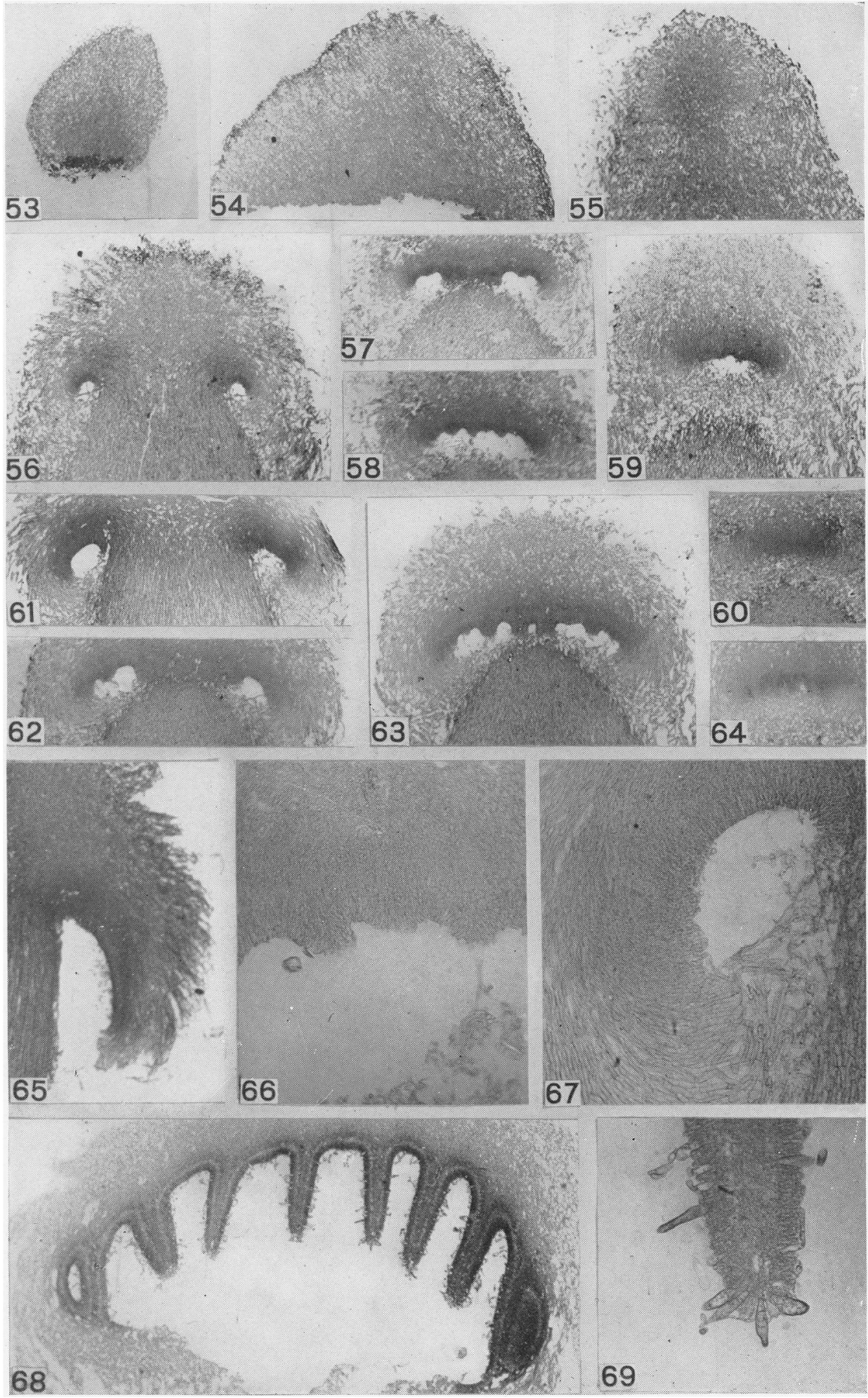

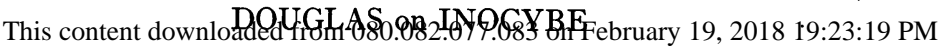

All use subject to University of Chicago Press Terms and Conditions (http://www.journals.uchicago.edu/t-and-c). 

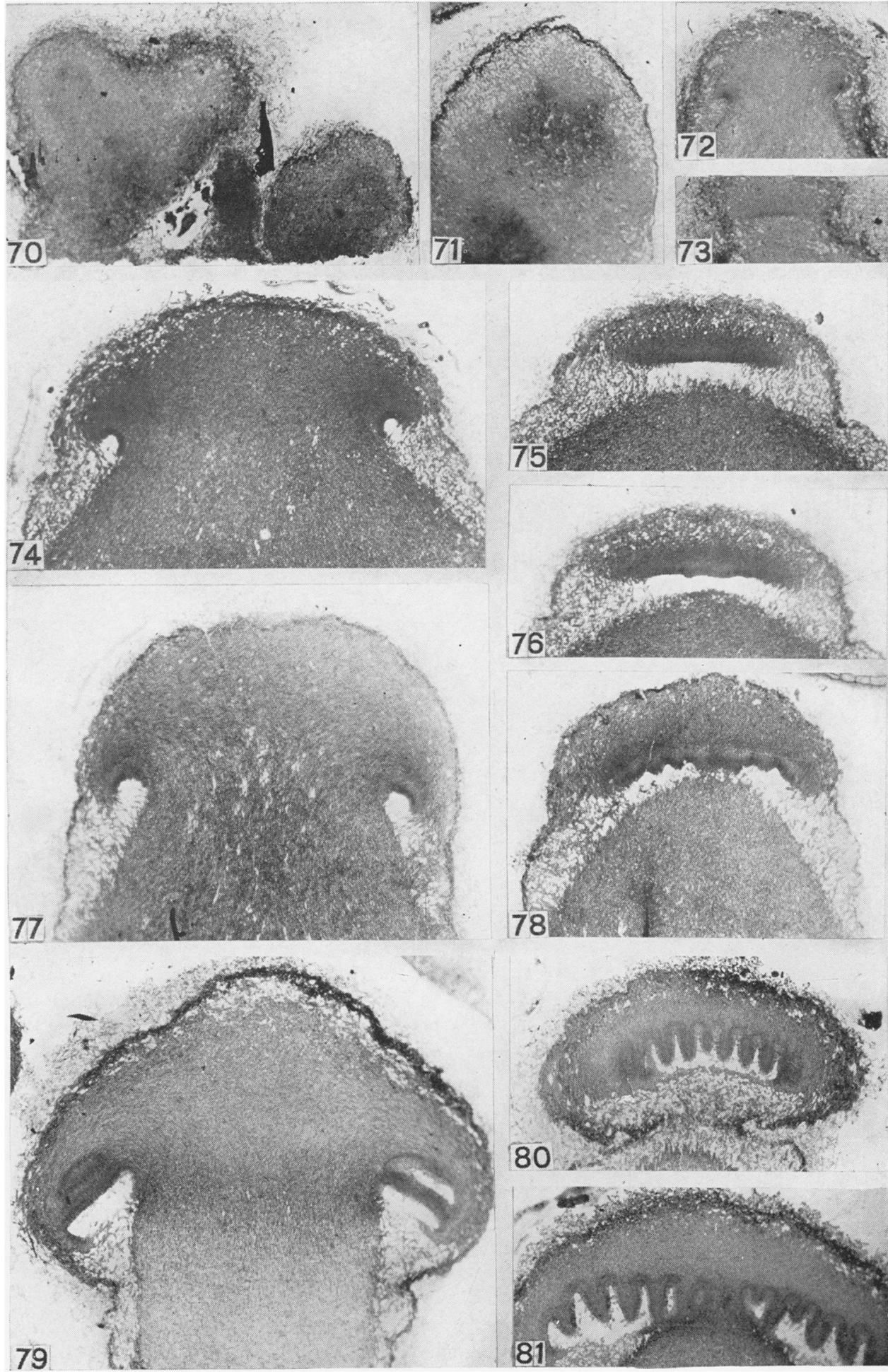

DOUGLAS on INOCYBE

This content downloaded from 080.082.077.083 on February 19, 2018 19:23:19 PM

All use subject to University of Chicago Press Terms and Conditions (http://www.journals.uchicago.edu/t-and-c). 